\title{
Prevalence of Bartonella infection in domestic cats in Denmark
}

\author{
Bruno B. Chomel ${ }^{\mathrm{a} *}$, Henri-Jean Boulouis ${ }^{\mathrm{b}}$, Hans Petersen ${ }^{\mathrm{c}}$, \\ Rickie W. Kasten ${ }^{\mathrm{a}}$, Kazuhiro YAMAMOTO ${ }^{\mathrm{a}}$, Chao-chin $\mathrm{CHANG}^{\mathrm{a}, \mathrm{d}}$, \\ Christelle GANDOIN ${ }^{b}$, Corinne Bouillin ${ }^{b}$, Carrie M. HEw ${ }^{a}$
}

\footnotetext{
${ }^{a}$ Department of Population Health and Reproduction, School of Veterinary Medicine, University of California, Davis, CA 95616, USA

bUMR 956, INRA/AFSSA/ENVA, École Nationale Vétérinaire, 7 avenue du Général de Gaulle, 94704 Maisons-Alfort, France

${ }^{\mathrm{c}}$ Hinnerup Animal Hospital, Dyrlaegegruppen Frijsenborg, Vestergade 3, 8382 Hinnerup, Denmark

${ }^{\mathrm{d}}$ Department of Public Health, Institute of Environmental Health, China Medical College, Taichung, Taiwan
}

(Received 23 July 2001; accepted 19 October 2001)

\begin{abstract}
Whole blood and serum from 93 cats (44 pets and 49 shelter/stray cats) from Denmark were tested for the presence of feline Bartonella species by culture and for the presence of Bartonella antibodies by serology. Bartonella henselae was isolated from $21(22.6 \%)$ cats. Bacteremia prevalence was not statistically different between shelter/stray cats $(13 / 49,26.5 \%)$ and pet cats $(8 / 44$, $18.2 \%$ ), but varied widely by geographical origin of the cats, even after stratification for cat origin or age $(p<0.001)$. All isolates but one were $B$. henselae type II. The only cat bacteremic with $B$. henselae type I was not co-infected with $B$. henselae type II. None of the cats was harboring either B. clarridgeiae or B. koehlerae. Almost half $(42 / 92,45.6 \%)$ of the cats were seropositive for $B$. henselae and antibody prevalence was similar in shelter/stray cats $(23 / 49,46.9 \%)$ and pet cats $(19 / 43,44.2 \%)$. This is the first report of isolation of $B$. henselae from domestic cats in Denmark. This study also indicates that domestic cats, including pet cats, constitute a large Bartonella reservoir in Denmark.
\end{abstract}

\section{Bartonella henselae / Denmark / domestic cat / Felis catus}

Résumé - Prévalence des infections à Bartonella sp. chez les chats domestiques au Danemark. Des prélèvements sanguins ont été réalisés sur 93 chats danois ( 44 chats de propriétaire et 49 chats de fourrière ou errants) afin d'établir la présence de Bartonelles par hémoculture et déterminer la prévalence en

\footnotetext{
* Correspondence and reprints

Tel.: (1) 530 752-8112; fax.: (1) 530-752-2377 or 752-5845; e-mail: bbchomel@ucdavis.edu
} 
anticorps anti-Bartonella. Bartonella henselae a été isolée de 21 (22,6\%) chats. Les prévalences de bactériémie n'étaient pas significativement différentes entre les chats de fourrière ou errants (13/49; $26,5 \%)$ et les chats de compagnie $(8 / 44 ; 18,2 \%)$, mais étaient différentes en fonction de l'origine géographique des chats, même après stratification $(p<0,001)$. Tous les isolats sauf un ont été identifiés comme appartenant au type II de $B$. henselae. Le seul chat infecté par $B$. henselae type I n'était pas co-infecté par $B$. henselae type II. Bartonella clarridgeiae et $B$. koehlerae n'ont été isolées d'aucun des chats. Presque la moitié $(42 / 92 ; 45,6 \%)$ des chats avaient des anticorps anti- $B$. henselae en immunofluorescence et la prévalence en anticorps était assez similaire chez les chats de fourrière ou errants $(23 / 49 ; 46,9 \%)$ et les chats de propriétaire $(19 / 43 ; 44,2 \%)$. Cette étude constitue la première mise en évidence de l'existence de Bartonella henselae chez les chats au Danemark et révèle que les chats domestiques, dont les chats de compagnie, représentent un réservoir important de Bartonelles au Danemark.

Bartonella henselae / chat domestique / Felis catus / Danemark

\section{INTRODUCTION}

Cat scratch disease is mainly caused by Bartonella henselae [13, 36], but $B$. clarridgeiae has also been linked to human cases of cat scratch disease [29, 31, 41]. The reservoir of Bartonella henselae and $B$. clarridgeiae is the domestic cat $[6,23,26$, $30,35]$, which can remain bacteremic for months to years $[1,18,27]$. Cat-to-human transmission occurs predominantly via a cat scratch or bite, whereas the cat flea (Ctenocephalides felis) is the primary vector of $B$. henselae from cat to cat $[11,16$, 24]. Most naturally infected cats appear to be asymptomatic, although clinical signs have been observed in some experimentally infected cats [18, 19, 28, 33]. Bartonella koehlerae has only been isolated from the blood of two naturally infected cats in northern California and its pathogenic potential for humans remains to be demonstrated [15].

Vascular proliferative diseases, such as bacillary angiomatosis and peliosis hepatis, and inflammatory conditions such as endocarditis, encephalitis, abscessation and leukocytoclastic vasculitis represent some of the diverse manifestations of Bartonella henselae infection in humans [8]. Bartonella henselae isolates differing in their 16S rRNA gene sequences (type I and type II) have been found infecting cats and humans $[5,6$, $14,23,39,40]$. It has been suggested that these types may differ in their pathogenicity $[3,5,6,37,40]$.

Previous epidemiological studies of Bartonella infection in domestic cats have demonstrated serological prevalences ranging from $4 \%$ to $81 \%$, and bacteremia prevalence of up to $60 \%[7,9,12,25,26]$. In Europe, Bartonella infection in cats, based on serology or bacterial isolation, has been reported from Austria [2], France [10, 20, 21, 23], Germany [3, 22, 39], Switzerland [17], The Netherlands [6], Portugal [7] and the United Kingdom [4]. In most of these countries, $B$. henselae type II was the most common type isolated from cats $[3,6,21,40]$. Bartonella clarridgeiae was isolated from $20 \%$ to $30 \%$ of the French cats tested [21, 23 ] and $16 \%$ of the Dutch cats [6], but was isolated from only one of the German cats tested $[3,39]$. No report of $B$. koehlerae isolation from cats in Europe has been published. No investigation of the presence of feline Bartonella infection in Denmark has been reported. The purpose of this study, using a convenience sample of pet and sheltered Danish cats, was to investigate the prevalence of infection (bacteremia and presence of antibodies) and identified the endemic Bartonella species in these cats. 


\section{MATERIALS AND METHODS}

\subsection{Animals}

A convenience sample of 93 cats, including 44 pet cats presented to various veterinary clinics, 40 cats from shelters in main cities across Denmark and 9 stray cats were enrolled in the study between August 27, 1998 and September 23, 1998. The cats were respectively from Northern and mid Jutland (mainland Denmark) (44 cats, including 28 pet cats, 11 shelter cats and 5 stray cats), southern Jutland (23 cats, including 10 pet cats and 13 shelter cats), and the cities of Odense (Island of Fynen) (17 cats, including 3 pet cats and 14 shelter cats) and Copenhagen (9 cats, including 3 pet cats, 2 shelter cats and 4 stray cats). One serum sample was not available from one of the cats. Most of the cats (74.2\%) were $\leq 2$ years old and males accounted for $57 \%$ of the 93 cats (Tab. I). All shelter/stray cats were less than 5 years old. For ectoparasite exposure, fleas were seen on 20 cats $(11(25 \%)$ pets and $9(18.4 \%)$ shelter/stray cats) and ticks on two cats (one pet and one shelter cat).

\subsection{Bartonella isolation from cat blood}

Three milliliters $(\mathrm{mL})$ of blood were aseptically drawn from peripheral veins. Two milliliters were collected into plastic ethylene diamine tetraacetate (EDTA) tubes (Becton Dickinson, Franklin Lakes, N.J., USA) for blood culture and $1 \mathrm{~mL}$ into serum separating tubes (Becton Dickinson, Franklin Lakes, N.J., USA) for serological tests. The EDTA tubes were frozen at $-70{ }^{\circ} \mathrm{C}$ until plated. Serum separating tubes were centrifuged at $500 \times g$, the serum removed and frozen at $-20^{\circ} \mathrm{C}$. Blood samples were cultured on heart infusion agar containing $5 \%$ rabbit blood for isolation of $B$. henselae or B. clarridgeiae [12] and onto chocolate agar plates for isolation of $B$. koehlerae, as previously described [15]. The plates were incubated at $35{ }^{\circ} \mathrm{C}$ with $5 \%$ $\mathrm{CO}_{2}$ for at least four weeks. Plates were examined 2-3 times a week for any bacterial growth. The number of colonies were counted and calculated as colony forming units $(\mathrm{CFU}) / \mathrm{mL}$. Colonies were Gram stained, sub-cultured, harvested and frozen at $-70{ }^{\circ} \mathrm{C}$ in $100 \%$ fetal calf serum.

\subsection{Identification of isolates}

Cat blood isolates were identified using polymerase chain reaction/restriction fragment length polymorphism analysis (PCRRFLP) of a fragment of the citrate synthase gene $[32,34]$, and a fragment of the 16S rRNA gene sequence analysis [38]. Isolated strains were confirmed to be $B$. henselae, B. clarridgeiae or B. koehlerae by PCR/RFLP of the citrate synthase gene

Table I. Population characteristics of 93 cats from Denmark.

\begin{tabular}{|c|c|c|c|c|c|c|c|c|}
\hline \multirow{2}{*}{$\begin{array}{l}\text { Age } \\
\text { (Year) }\end{array}$} & \multicolumn{2}{|c|}{ Pet } & \multicolumn{2}{|c|}{ Shelter } & \multicolumn{2}{|c|}{ Stray } & \multicolumn{2}{|c|}{ Total } \\
\hline & $\mathrm{M}$ & $\mathrm{F}$ & $\mathrm{M}$ & $\mathrm{F}$ & $\mathrm{M}$ & $\mathrm{F}$ & $\mathrm{M}$ & $\mathrm{F}$ \\
\hline 0 & 7 & 3 & 6 & 8 & 1 & 1 & 14 & 12 \\
\hline 1 & 6 & 1 & 10 & 7 & 0 & 1 & 16 & 9 \\
\hline 2 & 4 & 2 & 3 & 4 & 2 & 3 & 9 & 9 \\
\hline 3 & 4 & 1 & 0 & 1 & 0 & 1 & 4 & 3 \\
\hline 4 & 2 & 1 & 1 & 0 & 0 & 0 & 3 & 1 \\
\hline$\geq 5$ & 7 & 6 & 0 & 0 & 0 & 0 & 7 & 6 \\
\hline Total & 30 & 14 & 20 & 20 & 3 & 6 & 53 & 40 \\
\hline
\end{tabular}


(gltA) using HhaI and TaqI endonucleases, and the 16S-rRNA gene using DdeI restriction endonuclease [12, 15]. Positive control samples included DNA from the three references strains of $B$. henselae, $B$. clarridgeiae or $B$. koehlerae and a sample with no DNA template was used as a negative control. Rigorous precautions were taken not to contaminate the samples prior to gene amplification.

\subsection{Polymerase chain reaction/Restriction fragment length polymorphism (PCR/RFLP) procedures}

Isolates were analyzed using PCR/ RFLP of the gltA gene and the 16S-rRNA gene, as previously described [32, 34, 38]. After scraping off approximately $2 \mathrm{~cm}^{2}$ of confluent growth and suspending into $100 \mu \mathrm{L}$ sterile water, the bacterial suspension was heated at $100{ }^{\circ} \mathrm{C}$ for $15 \mathrm{~min}$ and then centrifuged at $15000 \times g$ for $10 \mathrm{~min}$ at $4{ }^{\circ} \mathrm{C}$. Finally, $1: 10$ dilution of the supernatant was used as DNA template. An approximate 400 base pairs (bp) fragment of the gltA gene and $1500 \mathrm{bp}$ fragment of the 16S-rRNA gene were amplified, and then verified by gel electrophoresis. The amplified product of the gltA gene obtained with the set of primers suggested by Norman et al. [32] was digested with TaqI (Promega, Madison, WI, USA) and HhaI (New England Lab., Beverly, MA, USA) restriction endonucleases. The amplified product of the 16S-rRNA gene was digested with $D d e \mathrm{I}$ (Boehringer Mannheim, GmbH, Germany) restriction endonuclease. The digestion conditions were the ones recommended by the enzymes' manufacturer. Banding patterns were compared with type strains of $B$. henselae Houston-1 (ATCC 49882), B. henselae type II (strain U4, U.C. Davis), B. clarridgeiae (ATCC 51734) and B. Koehlerae (ATCC 700693).

\subsection{Serological analysis}

Antibody titers against $B$. henselae were determined using an immunofluorescence assay (IFA), as previously described $[9,35$, 36]. Briefly, serum was serially diluted in PBS and incubated on slides containing FCWF (Felis catus whole fetus) cells infected with 16S-rRNA sequence confirmed strains of $B$. henselae type II (strain U4, UC Davis). The slides were washed and probed with FITC goat anti-cat $\operatorname{IgG}(\mathrm{H}+\mathrm{L})$ conjugate (Cappel, Organon Teknika Corp., Durham, N.C., USA) and the fluorescence was graded on a scale from 1 to 4 independently, by the same two readers. The endpoint titer was defined as the dilution for which an agreement of the two readers was obtained. Serum samples with a grade two fluorescence at a titer of $\geq 64$ were considered positive [9].

\subsection{Statistical analysis}

Non-parametric tests (chi-square test for homogeneity, two-tailed Fisher's exact test) performed with Epi Info 6.04b, were used to test for associations between culture positivity and putative risk factors, such as age, sex, origin, and flea infestation. Similar tests were performed to test for associations between seropositivity and the same risk factors. Stratified analysis was also performed to correct potential confounding effects caused by cat origin or age using SAS software version 8.2.

\section{RESULTS}

Bartonella henselae was isolated from $21(22.6 \%)$ cats. The number of colonies ranged from one colony forming unit (CFU)/mL to more than $2000 \mathrm{CFU} / \mathrm{mL}$ (Tab. II). Bacteremia prevalence was not statistically different between shelter/stray cats $(13 / 49,26.5 \%)$ and pet cats $(8 / 44$, $18.2 \%)$. The level of bacteremia $(\mathrm{CFU} / \mathrm{mL})$ 
Table II. Origin, number of colony forming units $(\mathrm{CFU}) / \mathrm{mL}$, Bartonella henselae type and IFA titer in 21 bacteremic cats from Denmark.

\begin{tabular}{ccccc}
\hline Cat ID \# & Origin* & CFU/mL & B. Henselae type & IFA titer \\
\hline DK10 & Sh & 1 & II & 128 \\
DK11 & Sh & 95 & II & 128 \\
DK12 & Sh & 2 & II & 512 \\
DK21 & Sh & 88 & II & 256 \\
DK27 & Sh & 1 & II & 128 \\
DK40 & P & 37 & II & 512 \\
DK41 & P & 7 & II & 0 \\
DK42 & St & 1 & II & 128 \\
DK65 & Sh & 1 & II & 128 \\
DK66 & Sh & 8 & II & 128 \\
DK70 & Sh & 87 & II & 256 \\
DK74 & Sh & 1 & II & 128 \\
DK77 & Sh & 907 & II & 0 \\
DK78 & P & 416 & I & 256 \\
DK82 & P & 259 & II & 128 \\
DK83 & P & 42 & II & 64 \\
DK84 & P & 5 & II & 256 \\
DK85 & P & $>2000$ & II & 128 \\
DK88 & P & 5 & II & 512 \\
DK91 & Sh & 91 & II & 512 \\
DK92 & Sh & 93 & II & 1024 \\
\hline
\end{tabular}

* P: pet, Sh: shelter, St: stray.

was not related to either the cat origin or the cat age. Bacteremia prevalence by locations was respectively $4.5 \%(2 / 44)$ for cats from northern/mid Jutland, 11.1\% (1/9) for cats from Copenhagen, $41.2 \%(7 / 17)$ for cats from Odense (Fynen Island) and 47.8\% $(11 / 23)$ for cats from southern Jutland, a difference statistically significant $(p<0.001)$. Cats from southern Jutland were 5.5 times (95\% confidence interval (C.I.) $=1.67$, 17.97) more likely to be bacteremic than cats from all other parts of Denmark. Cats from southern Jutland and Odense were 13.64 times $(95 \%$ C.I. $=3.37,77.22)$ more likely to be bacteremic than cats from northern/mid Jutland and Copenhagen. After stratification for cat origin (shelter/stray or pet), prevalence differences by geographical origin were still observed, with the highest bacteremia prevalence $(60 \%)$ observed in cats from southern Jutland (Tab. III). Age was not identified as a confounding factor. Among shelter/stray cats, bacteremia decreased with age in the $0-2$ years old group, as respectively $37.5 \%(6 / 16)$ of the less than one-year-old cats, $28 \%(5 / 18)$ of the oneyear-old cats and $8.3 \%(1 / 12)$ of the 2 -year-old cats were bacteremic. By comparison, none of the 10 pet cats $<1$ year-old were bacteremic, whereas $1(14.3 \%)$ of the 7 one-year-old pet cats and $1(16.7 \%)$ of the six 2-year-old pet cats were bacteremic. Three (15\%) of the 20 flea-infested cats and one of the two tick infested cats were bacteremic, whereas $17(23.9 \%)$ of the cats on which no fleas were observed were bacteremic. All isolates but one were $B$. henselae type II. The only cat bacteremic with $B$. henselae type I was a seven years old pet cat from southern Jutland that was 
Table III. Stratified analysis by origin and by age of the cats for the four geographical regions of Denmark.

\begin{tabular}{|c|c|c|c|c|}
\hline \multirow[b]{2}{*}{ Regions } & \multicolumn{2}{|c|}{ Pet } & \multicolumn{2}{|c|}{ Shetler/stray } \\
\hline & Bact. Pos. & Bact. Neg. & Bact. Pos. & Bact. Neg. \\
\hline North/Mid Jutland & 2 & 26 & 0 & 16 \\
\hline Copenhagen & 0 & 3 & 1 & 5 \\
\hline Odense (Fynen Is.) & 0 & 3 & 7 & 7 \\
\hline \multirow[t]{2}{*}{ South Jutland } & 6 & 4 & 5 & 8 \\
\hline & \multicolumn{2}{|c|}{ Age $<2$ years } & \multicolumn{2}{|c|}{ Age $\geq 2$ years } \\
\hline Regions & Bact. Pos. & Bact. Neg. & Bact. Pos. & Bact. Neg. \\
\hline North/Mid Jutland & 1 & 22 & 1 & 20 \\
\hline Copenhagen & 0 & 4 & 1 & 4 \\
\hline Odense (Fynen Is.) & 6 & 9 & 1 & 1 \\
\hline South Jutland & 5 & 4 & 6 & 8 \\
\hline
\end{tabular}

not co-infected with $B$. henselae type II (Tab. II). Neither B. clarridgeiae or $B$. koehlerae was cultured from any cat.

Almost half $(42 / 92,45.6 \%)$ of the cats were seropositive for $B$. henselae and antibody prevalence was similar in shelter/ stray cats $(23 / 49,46.9 \%)$ and pet cats $(19 / 43$, $44.2 \%)$. Among the 42 seropositive cats, almost two-third $(64.3 \%)$ of the cats were from southern Jutland or Odense. For cats from Copenhagen and Odense, seropositive cats were either shelter cats $(11 / 14$, $78.6 \%)$ in Odense or stray cats $(2 / 4,50 \%)$ in Copenhagen. There were more seropositive cats $(51.3 \%)$ among the 37 pet cats than among the 29 shelter/stray cats $(34.5 \%)$ from Jutland; however, that difference was not statistically significant. Seroprevalence by age groups was respectively $53.8 \%$ $(14 / 26)$ in the cats < 1 year-old, $40 \%$ $(10 / 25)$ in the 1 year-old group, $22 \%(4 / 18)$ in the 2 year-old group and $58.3 \%(14 / 24)$ in the $\geq 3$ year-old group. Cats with titers $\geq 512$ were mainly cats $\leq 2$ year-old $(6 / 7$, $86 \%)$ and culture positive cats $(5 / 7,71.4 \%)$. However, $2(9.5 \%)$ of the 21 culture positive cats were seronegative. Cats infested with fleas $(11 / 20,55 \%)$ were more frequently seropositive than cats not infested with fleas $(30 / 70,42.8 \%)$, but that difference was not statistically significant.

\section{DISCUSSION}

This is the first report of the presence of Bartonella infection in domestic cats in Denmark. As reported for cats in other European countries [3, 6, 10, 21, 23, 39, 40], $B$. henselae is common in this sample of Danish domestic cats. However, most of these studies, like ours, were performed on convenience samples that may not be fully representative of the cat population of these various countries. Nevertheless, the $26.5 \%$ prevalence of bacteremia observed in the 
Danish shelter/stray cats is in the range of values reported in sheltered cats in the Netherlands [6] or in stray cats in Berlin, Germany [3]. The bacteremia prevalence $(18.2 \%)$ in these Danish pet cats was slightly higher than the values (11-16.5\%) previously reported in similar studies for pet cats in other western European countries [10, 21, 39]. We observed geographical differences for bacteremia prevalence, even after stratification for cat origin or age, with the highest rates being found in cats from Southern Jutland and from Odense (Fynen Island). In Odense, all bacteremic animals were shelter cats, whereas in southern Jutland, both pet cats and shelter cats were bacteremic. Our data suggest a higher prevalence of $B$. henselae infection in cats from southern Denmark. However, such results will need to be validated on a larger sample of cats, randomly selected. Among young cats, shelter cats were more frequently bacteremic than pet cats. Presence of ectoparasites was not associated with presence of bacteremia.

All isolates but one belonged to the type II group of $B$. henselae. As previously reported for similar studies in many western European countries, $B$. henselae type II was the dominant Bartonella species and type isolated from domestic cats $[3,6,21$, 23]. The prevalence of feline $B$. henselae types in Danish cats was similar to that observed in cats from Germany [3, 40], with the limitation associated with the type of study (convenience sampling) performed in either Denmark or Germany. Prevalence of B. clarridgeiae appears to be quite low in Denmark, as previously observed in Germany, as neither this study nor the one by Sander et al. [39] were able to isolate this Bartonella species, and only one cat from Berlin was infected with $B$. clarridgeiae [3]. These data are in contrast to the higher prevalence of $B$. clarridgeiae observed in Dutch and French cats $[6,21,23]$. Despite all our attempts to isolate $B$. koehlerae on specific media, no culture from our cat pop- ulation yielded this new feline Bartonella, only reported from domestic cats from northern California [15].

Bartonella henselae antibodies were detected in $46.7 \%$ of the cats, suggesting that this infection is widespread in the Danish cats we studied, but seropositive cats were mainly from southern Jutland and from Odense. Such a prevalence is within the range of values reported in similar studies on a convenience sample of cats from various parts of Western Europe [4, 6, 21], but is higher than the prevalence reported in pet cats from Switzerland (8.3\%) or from Germany $(15 \%)[17,22]$. As previously reported, cats with high antibody titers $(\geq 512)$ are more likely to be bacteremic [9], but some cats can be bacteremic without any antibodies $[9,30]$.

In conclusion, the epidemiology of Bartonella infection in Danish cats appears similar to the epidemiology of the infection in German cats, as far as Bartonella species and type are concerned, and differs from what has been reported for cats from either France or the Netherlands. This study suggests that infection is common in Danish domestic cats, which represent an important reservoir of infection for humans.

\section{ACKNOWLEDGMENTS}

This project was funded in part by a grant from Novartis Animal Health, Denmark, Bayer Denmark Veterinary Division, Orion Pharma (Pfizer), Vet Fonden Logumkloster DK and Statens Serum Institut, Copenhagen.

\section{REFERENCES}

[1] Abbott R.C., Chomel B.B., Kasten R.W., Floyd-Hawkins K.A., Kikuchi Y., Koehler J.E., Pedersen N.C., Experimental and natural infection with Bartonella henselae in domestic cats, Comp. Immunol. Microbiol. Infect. Dis. 20 (1997) 41-51. 
[2] Allerberger F., Schonbauer M., Zangerle R., Dierich M., Prevalence of antibody to Rochalimaea henselae among Austrian cat, Eur. J. Ped. 154 (1995) 165.

[3] Arvand M., Klose A.J., Schwartz-Porsche D., Hahn H., Wendt C., Genetic variability and prevalence of Bartonella henselae in cats in Berlin, Germany, and analysis of its genetic relatedness to a strain from Berlin that is pathogenic for humans, J. Clin. Microbiol. 39 (2001) 743-746.

[4] Barnes A., Bell S.C., Isherwood D.R., Bennett M., Carter S.D., Evidence of Bartonella henselae infection in cats and dogs in the United Kingdom, Vet. Rec. 147 (2000) 673-677.

[5] Bergmans A.M.C., Schellenkens J.F.P., van Embden J.D.A., Schouls L.M., Predominance of two Bartonella henselae variants among catscratch disease patients in The Netherlands, J. Clin. Microbiol. 34 (1996) 254-260.

[6] Bergmans A.M.C., de Jong C.M.A., van Amerongen G., Schot C.S., Schouls L.M., Prevalence of Bartonella species in domestic cats in The Netherlands, J. Clin. Microbiol. 35 (1997) 2256-2261.

[7] Childs J.E., Olson J.G., Wolf A., Cohen N., Fakile Y., Rooney J.A., Bacellar F., Regnery R.L., Prevalence of antibodies to Rochalimaea species (cat-scratch disease agent) in cats, Vet. Rec. 20 (1995) 519-520.

[8] Chomel B.B., Cat scratch disease, Rev. Sci. Tech. Off. Int. Epiz. 19 (2000) 136-150.

[9] Chomel B.B., Abbott R.C., Kasten R.W., Floyd-Hawkins K.A., Kass P.H., Glaser C.A., Pedersen N.C., Koehler J.E., Bartonella henselae prevalence in domestic cats in California: risk factors and association between bacteremia and antibody titers, J. Clin. Microbiol. 33 (1995) 2445-2450.

[10] Chomel B.B., Gurfield A.N., Boulouis H.J., Kasten R.W., Piemont Y., Réservoir félin de l'agent de la maladie des griffes du chat, Bartonella henselae, en région parisienne: résultats préliminaires, Rec. Méd. Vét. 171 (1995) 841-845.

[11] Chomel B.B., Kasten R.W., Floyd-Hawkins K., Chi B., Yamamoto K., Roberts-Wilson J., Gurfield A.N., Abbott R.C., Pedersen N.C., Koehler J.E., Experimental transmission of Bartonella henselae by the cat flea, J. Clin. Microbiol. 34 (1996) 1952-1956.

[12] Chomel B.B., Carlos E.T., Kasten R.W., Yamamoto K., Chang C.C., Carlos R.S., Abenes M.V., Pajares C.M., Bartonella henselae and Bartonella clarridgeiae infection in domestic cats from The Philippines, Am. J. Trop. Med. Hyg. 60 (1999) 593-597.

[13] Dolan J.M., Wong M.T., Regnery R.L., Jorgensen J.H., Garcia M., Peters J., Drehner D., Syndrome of Rochalimaea henselae adenitis suggesting cat scratch disease, Ann. Intern. Med. 118 (1993) 331-336.

[14] Drancourt M, Birtles R., Chaumentin G., Vandenesch F., Etienne J., Raoult D., New serotype of Bartonella henselae in endocarditis and cat-scratch disease, Lancet 347 (1996) 441-443.

[15] Droz S., Banghee C., Horn E., Steigerwalt A.G., Whitney A.M., Brenner D.J., Bartonella koehlerae sp. nov., isolated from cats, J. Clin. Microbiol. 37 (1999) 1117-1122.

[16] Foil L., Andress E., Freeland R.L., Roy A.F., Rutledge R., Triche P.C., O’Reilly K.L., Experimental infection of domestic cats with Bartonella henselae by inoculation of Ctenocephalides felis (Siphonaptera: Pulicidae) feces, J. Med. Entomol. 35 (1998) 625-628.

[17] Glaus T., Hofmann-Lehmann R., Greene C., Glaus B., Wolfensberger C., Lutz H., Seroprevalence of Bartonella henselae infection and correlation with disease status in cats in Switzerland, J. Clin. Microbiol. 35 (1997) 2883-2885.

[18] Guptill L., Slater L., Wu C.C., Lin T.L., Glickman L.T., Welch D.F., HogenEsch H., Experimental infection of young specific pathogen-free cats with Bartonella henselae, J. Infect. Dis. 176 (1997) 206-216.

[19] Guptill L., Slater L.N., Wu C.C., Lin T.L., Glickman L.T., Welch D.F., Tobolski J., HogenEsch H., Evidence of reproductive failure and lack of perinatal transmission of Bartonella henselae in experimentally infected cats, Vet. Immunol. Immunopathol. 65 (1998) 177-189.

[20] Gurfield A.N., Boulouis H.J., Chomel B.B., Heller R., Kasten R.W., Yamamoto K., Piemont Y., Coinfection with Bartonella clarridgeiae and Bartonella henselae and with different Bartonella henselae strains in domestic cats, J. Clin. Microbiol. 35 (1997) 2120-2123.

[21] Gurfield A.N., Boulouis H.J., Chomel B.B., Kasten R.W., Heller R., Bouillin C., Gandoin C., Thibault D., Chang C.C., Barrat F., Piemont Y., Epidemiology of Bartonella infection in domestic cats in France, Vet. Microbiol. 80 (2001) 185-198

[22] Haimerl M., Tenter A.M., Simon K., Rommel M., Hilger J., Autenrieth I.B., Seroprevalence of Bartonella henselae in cats in Germany, J. Med. Microbiol. 48 (1999) 849-856.

[23] Heller R., Artois M., Xemar V., de Briel D., Gehin H., Jaulhac B., Monteil H., Piemont Y., Prevalence of Bartonella henselae and Bartonella clarridgeiae in stray cats, J. Clin. Microbiol. 35 (1997) 1327-1331.

[24] Higgins J.A., Radulovic S., Jaworski D.C., Azad A.F., Aquisition of the cat scratch disease agent Bartonella henselae by cat fleas (Siphonaptera: Pulicidae), J. Med. Entomol. 33 (1996) 490- 495.

[25] Jameson P., Greene C., Regnery R., Dryden M., Marks A., Brown J., Cooper J., Glaus B., Greene 
R., Prevalence of Bartonella henselae antibodies in pet cats throughout regions of North America, J. Infect. Dis. 172 (1995) 1145-1149.

[26] Koehler J.E., Glaser C.A., Tappero J.W., Rochalimaea henselae infection. A new zoonosis with the domestic cat as reservoir, J. Am. Med. Assoc. 271 (1994) 531-535.

[27] Kordick D.L., Wilson K.H., Sexton D.J., Hadfield T.L., Berkhoff H.A., Breitschwerdt E.B., Prolonged Bartonella bacteremia in cats associated with cat-scratch disease patients, J. Clin. Microbiol. 33 (1995) 3245-3251.

[28] Kordick D.L., Breitschwerdt E.B., Relapsing bacteremia after blood transmission of Bartonella henselae to cats, Am. J. Vet. Res. 58 (1997) 492-497.

[29] Kordick D.L., Hilyard E.J., Hadfield T.L., Wilson K.H., Steigerwalt A.G., Brenner D.J., Breitschwerdt E.B., Bartonella clarridgeiae, a newly recognized zoonotic pathogen causing inoculation papules, fever and lymphadenopathy (cat scratch disease), J. Clin. Microbiol. 35 (1997) 1813-1818.

[30] Kordick D.L., Papich M.G., Breitschwerdt E.B., Efficacy of enrofloxacin or doxycycline for treatment of Bartonella henselae or Bartonella clarridgeiae infection in cats, Antimicrob. Agents Chemother. 41 (1997) 2448-2455.

[31] Margileth A.M., Baehren D.F., Chest-wall abscess due to cat-scratch disease (CSD) in an adult with antibodies to Bartonella clarridgeiae: case report and review of the thoracopulmonary manifestations of CSD, Clin. Infect. Dis. 27 (1998) 353-357.

[32] Norman A.F., Regnery R., Jameson P, Greene C., Krause D.C., Differentiation of Bartonella-like isolates at the species level by PCR-restriction fragment length polymorphism in the citrate synthase gene, J. Clin. Microbiol. 33 (1995) 1797-1803.

[33] O’Reilly K.L., Bauer R.W., Freeland R.L., Foil L.D., Hughes K.J., Rohde K.R., Roy A.F., Stout
R.W., Triche P.C., Acute clinical disease in cats following infection with a pathogenic strain of Bartonella henselae (LSU16), Infect. Immun. 67 (1999) 3066-3072.

[34] Regnery R.L., Anderson B.E., Clarridge III J.E., Rodriguez-Barradas M.C., Jones D.C., Carr J.H., Characterization of a novel Rochalimaea species, $R$. henselae sp. nov., isolated from blood of a febrile, human immunodeficiency viruspositive patient, J. Clin. Microbiol. 30 (1992) 265-274.

[35] Regnery R.L., Martin M., Olson J.G., Naturally occurring Rochalimaea henselae infection in domestic cat, Lancet 340 (1992) 557-558.

[36] Regnery R.L., Olson J.G., Perkins B.A., Bibb W., Serological response to "Rochalimaea henselae" antigen in suspected cat-scratch disease, Lancet 339 (1992) 1443-1445.

[37] Relman D.A., Editorial response: Are all Bartonella henselae strains created equal? Clin. Infect. Dis. 26 (1998) 1300-1301.

[38] Relman D.A., Loutit J.S., Schmidt T.M., Falkow S., Tompkins L.S., The agent of bacillary angiomatosis: an approach to the identification of uncultured pathogens, N. Engl. J. Med. 323 (1990) 1573-1580

[39] Sander A., Bühler C., Pelz K., Von Cramm E., Bredt W., Detection and identification of two Bartonella henselae variants in domestic cats in Germany, J. Clin. Microbiol. 35 (1997) 584-587.

[40] Sander A., Ruess M., Bereswill S., Schuppler M., Steinbrueckner B., Comparison of different DNA fingerprinting techniques for molecular typing of Bartonella henselae isolates, J. Clin. Microbiol. 36 (1998) 2973-2981.

[41] Sander A., Zagrosek A., Bredt W., Schiltz E., Piemont Y., Lanz C., Dehio C., Characterization of Bartonella clarridgeiae flagellin (FlaA) and detection of antiflagellin antibodies in patients with lymphadenopathy, J. Clin. Microbiol. 38 (2000) 2943-2948.

To access this journal online: www.edpsciences.org 